\title{
HUBUNGAN PENGETAHUAN DAN SIKAP DENGAN PENCEGAHAN KECELAKAAN KERJA PADA PETUGAS PENGANGKUT SAMPAH DOMESTIK DI TPA CAHAYA KENCANA
}

\section{THE RELATIONSHIP OF KNOWLEDGE AND ATTITUDE WITH WORK ACCIDENT PREVENTION ON DOMESTIC WASTE TRANSPORTER OFFICERS IN TPA CAHAYA KENCANA}

\author{
M. Jamaludin ${ }^{1}$, Akhmad Fauzan ${ }^{2 *}$ \\ 1,2,3Fakultas Kesehatan Masyarakat, Universitas Islam Kalimantan (UNISKA) MAB \\ Banjarmasin \\ Jl. Adhyaksa. No.2. Kota Banjarmasin, Kalimantan Selatan. Indonesia \\ *Email: akhmadfauzan.fkmuniska@gmail.com
}

\begin{abstract}
Work accidents are a problem that needs to be considered and faced by every worker where every time it occurs and without being known. The high risk of work accidents, workers are required to be more concentrated at work. Good behavior can be formed by its components, namely knowledge and attitudes that can be reflected in actions. The purpose of this study was to determine the relationship between knowledge and attitudes with the prevention of work accidents for domestic waste transport officers at the Cahaya Kencana TPA, Padang Panjang Village, Karang Intan District, Banjar Regency in 2020. The research method was observational analytic with a cross sectional approach. The number of samples is 58 people with total sampling technique. The instrument is a questionnaire. The test used is Chi Square. The results show that work accident prevention efforts are included in the sufficient category as much as $65.5 \%$, the level of knowledge is sufficient as much as $55.2 \%$, negative attitude as much as $53.4 \%$. The conclusion is that there is a significant relationship between knowledge, $p$ value 0.003 , and attitude $p$ value $0.001<0.05$ with efforts to prevent work accidents for domestic waste transport officers at TPA Cahaya Kencana, Padang Panjang Village, Karang Intan District, Banjar Regency in 2020. Suggestions provide information about the importance of aspects technical safety dams provide complete safety equipment and meet safety standards
\end{abstract}

Keywords: Work Accident Prevention; Knowledge; Attitude; Domestic Waste

\begin{abstract}
ABSTRAK
Kecelakaan kerja adalah suatu permasalahan yang perlu diperhatikan dan dihadapi oleh setiap pekerja dimana setiap waktu kapan terjadi dan tanpa diketahui Tingginya risiko kecelakaan kerja para pekerja dituntut untuk lebih konsentrasi dalam bekerja. Perilaku yang baik dapat dibentuk oleh komponen-komponennya yaitu pengetahuan dan sikap yang dapat tercermin dalam tindakan. Tujuan untuk mengetahui hubungan pengetahuan dan sikap dengan pencegahan kecelakaan kerja pada petugas pengangkut sampah domestik di TPA Cahaya Kencana Desa Padang Panjang Kecamatan Karang Intan Kabupaten Banjar tahun 2020. Metode penelitian analitik observasional dengan pendekatan cross sectional. Jumlah sampel 58 orang dengan teknik pengambilan total sampling. Instrumen berupa kuesioner. Uji yang digunakan Chi Square. Hasil menunjukkan upaya pencegahan kecelakaan kerja termasuk dalam kategori cukup sebanyak $65,5 \%$, tingkat pengetahuan cukup sebanyak $55,2 \%$, bersikap negatif sebanyak $53,4 \%$. Kesimpulan ada hubungan yang bermakna pengetahuan $p$ value 0,003 , dan sikap $p$ value $0,001<0,05$ dengan upaya pencegahan kecelakaan kerja pada petugas pengangkut sampah domestik di TPA Cahaya Kencana Desa Padang Panjang kecamatan Karang Intan kabupaten Banjar tahun 2020. Saran memberikan informasi tentang pentingnya aspek teknis keselamatan kerja dam memberikan peralatan keselamatan kerja yang lengkap dan memenuhi standar keselamatan
\end{abstract}

Kata kunci : Pencegahan Kecelakaan Kerja; Pengetahuan; Sikap; Sampah Domestik 


\section{PENDAHULUAN}

Di Indonesia rata-rata per tahun terdapat 99.000 kasus kecelakaan kerja, sekitar $70 \%$ berakibat fatal yaitu kematian dan cacat seumur hidup. Data BPJS Ketenagakerjaan tahun 2015 menunjukkan kecelakaan kerja sejumlah 105.182 kasus dengan korban meninggal dunia sebanyak 2.375 orang. Tahun 2014 yaitu 24.910 dan tahun 2013 yaitu 35.917 kasus. Data dari TPA Cahaya Kencana desa Padang panjang kecamatan Karang Intan kabupaten Banjar bahwa pada tahun 2019 lebih dari 50\% petugas pengangkut sampah domestik tidak menggunakan APD walaupun APD yang ada di tempat tersebut sudah ada dalam jumlah terbatas sehingga angka kecelakaan kerja yang terjadi disana cukup besar sekitar 30-40\% setiap tahunnya (1).

Kecelakaan kerja adalah suatu kejadian yang tidak diduga dan tidak dikehendaki yang mengacaukan proses suatu aktivitas yang sudah telah diatur. Kecelakaan akibat kerja juga berhubungan dengan hubungan kerja pada perusahaan. Hubungan kerja disini dapat berarti bahwa kecelakaan terjadi dikarenakan pekerjaaun atau pada waktu pekerjaan berlangsung (2). Hasil penelitian yang dilakukan Thaha (2017) menyebutkan kecelakaan yang dialami petugas pengangkut sampah yaitu tertusuk dan tergores saat bekerja, terjatuh, dan mengalami patah tulang (3).

Hasil observasi dan wawancara dilakukan oleh peneliti pada tanggal 19 Maret 2020 di lokasi tempat pembuangan sampah domestik TPA Cahaya Kencana desa Padang Panjang kecamatan Karang Intan Kabupaten Banjar pada 2 (dua) orang pekerja tidak mengetahui tentang upaya pencegahan kecelakaan kerja terlihat hampir sebagian besar tidak memakai APD. Kecelakaan kerja yang sering terjadi di lokasi ini seperti luka pada bagian tangan atau kaki dan sebagian kecil meletakkan perkakas di sembarang tempat tanpa dilengkapi dengan penutup atau alas pelindung.

Tujuan penelitian adalah untuk mengidentifikasi dan mengetahui hubungan pengetahuan dan sikap dengan pencegahan kecelakaan kerja pada petugas pengangkut sampah domestik di TPA Cahaya Kencana desa Padang Panjang Kecamatan Karang Intan Kabupaten Banjar tahun 2020.

\section{ALAT DAN METODE}

Rancangan penelitian adalah analitik observasional dengan menggunakan pendekatan cross sectional. Populasi adalah seluruh petugas pengangkut sampah domestik di TPA Cahaya
Kencana desa Padang Panjang Kecamatan Karang Intan Kabupaten Banjar tahun 2020 yang berjumlah 60 orang dan sampel sebanyak 58 orang. Teknik pengambilan data dengan total sampling. Variabel bebas (pengetahuan dan sikap petugas pengangkut sampah domestik) dan variabel terikat (upaya pencegahan kecelakaan kerja). Instrumen data berupa kuesioner, wawancara dan dokumentasi. Teknik pengumpulan data (data primer dan sekunder). Pengolahan data (editing, coding, skoring, entry dan tabulating). Pada analisis univariate menggunakan teknik perhitungan persentase dan ditampilkan dalam bentuk tabel dan sedangkan bivariate menggunakan uji Chi Square dengan $p$ value $<0,05$.

\section{HASIL DAN PEMBAHASAN}

\section{Karakteristik Responden}

Tabel 1. Karakteristik Responden Para Petugas Pengangkut Sampah Domestik Di TPA Cahaya Kencana Padang Panjang

\begin{tabular}{lcc}
\hline \multicolumn{1}{c}{ Karakteristik Responden } & $\mathbf{n}$ & $\mathbf{\%}$ \\
Umur & & \\
$<20$ tahun & 2 & 3,4 \\
20-30 tahun & 18 & 31,1 \\
$>30-40$ tahun & 29 & 50,0 \\
$>40-50$ tahun & 5 & 8,6 \\
$>50$ tahun & 4 & 6,9 \\
Pendidikan & & \\
SD/sederajat & 6 & 10,3 \\
SLTP/sederajat & 14 & 24,2 \\
SLTA/sederajat & 25 & 60,3 \\
Diploma & 3 & 5,2 \\
Sarjana & 0 & 0,0 \\
Lama bekerja & & \\
$<1$ tahun & 2 & 3,4 \\
1-2 tahun & 20 & 34,5 \\
$>$ 2-3 tahun & 29 & 50,0 \\
$>3$ tahun & 7 & 12,1 \\
Total & $\mathbf{5 8}$ & $\mathbf{1 0 0}$ \\
\hline
\end{tabular}

Tabel 1 pada karakteristik responden sebagian besar berusia sekitar $>30-40$ tahun $(50,0 \%)$, latar pendidikan SMA/sederajat $(60,3 \%)$ dan lama bekerja $>2-3$ tahun $(50,0 \%)$. 
Tabel 2. Distribusi Responden Berdasarkan Upaya Pencegahan Kecelakaan Kerja, Pengetahuan dan sikap Para Petugas Pengangkut Sampah Domestik Di TPA Cahaya Kencana Padang Panjang

\begin{tabular}{lcc}
\hline Upaya Pencegahan Kecelakaan Kerja & n & $\%$ \\
Kurang & 0 & 0,0 \\
Cukup & 38 & 65,5 \\
Baik & 20 & 35,4 \\
Pengetahuan & & \\
Kurang & 10 & 17,2 \\
Cukup & 32 & 55,2 \\
Baik & 16 & 27,6 \\
Sikap & & \\
Negatif & 31 & 53,4 \\
Positif & 27 & 46,6 \\
& & \\
Total & 58 & 100 \\
\hline
\end{tabular}

Tabel 2 sebagian besar upaya pencegahan kecelakaan kerja cukup (65,5\%). Upaya pencegahan kecelakaan kerja dikatakan cukup terlihat para pekerja melakukan sesuai dengan SOP. Penggunaan APD dapat dikatakan sudah memenuhi standar meskipun ada beberapa orang yang terlihat tidak lengkap. Saat wawancara jika ada pekerja yang melakukan kesalahan biasanya langsung diberikan teguran dan surat peringatan dari pimpinan. Pada Variabel pengetahuan, sebagian besar berpengetahuan cukup $(55,2 \%)$.
Pengetahuan sebagian besar cukup. Terlihat setiap pekerjaan dilakukan sesuai prosedur, setiap melakukan aktivitas menggunakan APD. Hasil wawancara menunjukkan saat peneliti menanyakan tentang manfaat APD sebagian besar pekerja dapat menjawab dengan benar seperti APD digunakan untuk melindungi dari kecelakaan kerja dan penyakit kerja, pertanyaan menyangkut fungsi alat kerja yang digunakan sebagian besar para pekerja dapat menjawab fungsi dari alat tersebut (4).

Pada variable sikap, sebagian besar bersikap negatif $(53,4 \%)$. Hasil wawancara mengenai sikap sebagian besar bersikap negatif meskipun pengetahuan yang dimiliki termasuk kategori cukup. Pengetahuan yang dimiliki oleh pekerja terkadang tidak diterapkan pada kenyataan sehari-hari seperti penggunaan masker atau penutup mulut saat melakukan pekerjaan hanya sesaat menggunakannya karena dengan alasan merasa kesulitan dalam bernafas, sebagian tidak menggunakan sepatu boot karena jika terlalu lama menggunakan sepatu boot kaki para pekerja akan mengalami lecet akibat lembab, tidak konsentrasi dalam bekerja seperti sambil bercanda tawa dan berbincang-bincang saat bekerja (5).

Tabel 3. Hubungan Pengetahuan Dengan Upaya Pencegahan Kecelakaan Kerja Pada Petugas Pengangkut Sampah Domestik Di TPA Cahaya Kencana Desa Padang Panjang

\begin{tabular}{|c|c|c|c|c|c|c|c|c|c|}
\hline \multirow[t]{3}{*}{ Variabel } & \multicolumn{6}{|c|}{ Pencegahan Kecelakaan Kerja } & \multicolumn{2}{|c|}{ Total } & \multirow[t]{3}{*}{ P Value } \\
\hline & \multicolumn{2}{|c|}{ Kurang } & \multicolumn{2}{|c|}{ Cukup } & \multicolumn{2}{|c|}{ Baik } & & & \\
\hline & $\mathbf{n}$ & $\%$ & $\mathbf{n}$ & $\%$ & $\mathbf{N}$ & $\%$ & $\mathbf{n}$ & $\%$ & \\
\hline Pengetahuan & 0 & 0 & 8 & 80,0 & 2 & 20,0 & 10 & 100 & 0,003 \\
\hline Kurang & 0 & 0 & 25 & 78,1 & 7 & 21,9 & 32 & 100 & \\
\hline Cukup & 0 & 0 & 5 & 31,2 & 11 & 68,8 & 16 & 100 & \\
\hline Baik & & & & & & & & & \\
\hline Sikap & 0 & 0 & 27 & 87,1 & 4 & 12,9 & 31 & 100 & 0,001 \\
\hline Negatif & 0 & 0 & 11 & 40,7 & 16 & 59,3 & 27 & 100 & \\
\hline Positif & 0 & 0 & 38 & 65,5 & 20 & 34,5 & 58 & 100 & \\
\hline
\end{tabular}




\section{Hubungan Pengetahuan Dengan Upaya Pencegahan Kecelakaan Kerja Pada Petugas Pengangkut Sampah Domestik Di TPA Cahaya Kencana Desa Padang Panjang}

Tabel 3 terlihat sebagian besar responden berpengetahuan cukup dan menunjukan upaya pencegahan kecelakaan kerja cukup 78,1\%. Hasil uji statistik diperoleh nilai $p$ value $=0,003<a 0,05$. Ini menunjukkan bahwa ada hubungan yang bermakna antara pengetahuan dengan upaya pencegahan kecelakaan kerja pada petugas pengangkut sampah domestik di TPA Cahaya Kencana Desa Padang Panjang Kecamatan Karang Intan Kabupaten Banjar tahun 2020.

Pengetahuan yang cukup didapatkan dari informasi atau bimbingan dari petugas, pelatihan yang sudah diikuti oleh para pekerja, pengalaman selama bekerja karena sebagian besar para pekerja bekerja dengan kurun waktu yang cukup lama yaitu $>2$ tahun. Jika dilihat dari tingkat pendidikan sebagian besar pekerja berlatar pendidikan SMA/sederajat. Pengetahuan sangat erat hubungannya dengan pendidikan.

Penelitian Latifatul (2016) (6), menyebutkan adanya hubungan antara pengetahuan keselamatan kerja dengan pelaksanaan pencegahan kecelakaan kerja dengan nilai $p$ value 0,001 . Penelitian Anton (2011) ada hubungan yang bermakna antara pengetahuan keselamatan kerja dengan kewaspadaan kecelakaan kerja pada karyawan dengan nilai koefisien kontinengsi sebesar 1,00. Penelitian Dwi (2014) menyebutkan ada hubungan yang positif dan signifikan pengetahuan dengan perilaku pencegahan kerja di Laboratorium Farmasi Poltekes Bhakti Mulia dengan $p$ value 0,013<0,05 (4) .

Pengetahuan yang diteliti adalah pengetahuan mengenai kesehatan dan keselamatan kerja. pengetahuan yang rendah belum tentu berisiko tinggi mengalami dermatitis kontak. Pengetahuan yang tinggi, belum dapat mencegah terjadinya risiko dermatitis kontak, hal ini dimungkinkan karena pengetahuan tersebut hanya sekedar tahu, sehingga pengetahuan tersebut belum dicerminkan pada tindakan sehari-hari. Penerapan kesehatan dan keselamatan kerja masih sangat kurang. Pekerja yang tidak mengetahui prosedur kerja maka mereka akan bekerja dengan caranya sendiri, lebih mementingkan kenyamanan bekerja tanpa memperhatikan kesehatan dan keselamatan kerja (7).

\section{Hubungan Sikap Dengan Upaya Pencegahan Kecelakaan Kerja Pada Petugas Pengangkut Sampah Domestik Di TPA Cahaya Kencana Desa Padang Panjang}

Tabel 3 terlihat sebagian besar responden Bersikap negatif dan menunjukkan upaya pencegahan kecelakaan kerja cukup $87,1 \%$. Hasil uji statistik diperoleh nilai $p$ value $=0,001<a 0,05$. Ini menunjukkan bahwa ada hubungan yang bermakna antara sikap dengan upaya pencegahan kecelakaan kerja pada petugas pengangkut sampah domestik di TPA Cahaya Kencana Desa Padang Panjang Kecamatan Karang Intan Kabupaten Banjar tahun 2020.

Sikap adalah respon tertutup seseorang terhadap suatu stimulus atau objek, baik yang bersifat intern maupun ekstern sehingga manifestasinya tidak dapat langsung dilihat, tetapihanya dapat ditafsirkan terlebih dahulu dari pengetahuan yang tertutup tersebut. Sikap secara realitas menunjukkan adanya kesesuaian respon terhadap stimulus tertentu. Sikap negatif terlihat masih terdapat para pekerja yang tidak mengikuti SOP saat bekerja. Meskipun pengetahuan yang dimiliki para pekerja cukup tetapi di lapangan masih banyak pekerja yang tidak menggunakannya, walaupun telah diketahui besarnya manfaat alat ini (8).

Penelitian ini menunjukan bahwa sikap para pekerja pengangkut sampah terhadap penggunaan alat pelindung diri baik, akan tetapi meskipun sikap pekerja pengangkut sampah sudah baik ada beberapa faktor yang mempengaruhi penggunaan alat pelindung diri (APD), seperti kenyamanan dalam bekerja. Sebagian besar pekerja tidak menggunakan alat pelindung diri masker yaitu sebanyak 26 responden atau $72 \%$ tidak menggunakan masker karena mereka merasa kesulitan bernapas saat melakukan pengangkutan sampah, dan sebagian besar pekerja tidak menggunakan alat pelindung sarung tangan sebanyak 33 responden atau 92\% tidak menggunakan sarung tangan karena pekerja pengangkut sampah merasa tidak nyaman saat bekerja mengangkut sampah (9).

Penelitian Edwina (2017) (10), menunjukkan terdapat hubungan signifikan secara bersama-sama pengetahuan keselamatan dan kesehatan kerja dan sikap penggunaan alat pelindung diri terhadap 
kejadian kecelakaan kerja pengrajin pisau batik PT. X

\section{DAFTAR PUSTAKA}

1. Profil TPA Cahaya Kencana, 2020.Mengenal Lebih dekat TPA Cahaya Kencana Tempat Pemprosesan Akhir Sampah Yang Berwawasan Dan Ramah Limbah

2. Hamsir, Peletean Dewi, Rostina. 2020. Hubungan Pengetahuan Dan Sikap Pekerja Pengangkut Sampah Dengan Penggunaan Alat Pelindung Diri (APD) Di Kota Makassar. Jurnal Jurnal Sulolipu : Media Komunikasi Sivitas Akademika dan Masyarakat Vol. 20 No.2 2020.

3. Thaha, A. I. (2017). Gambaran Kecelakaan Kerja, penyakit akibat kerja dan postur janggal pada pekerja armada mobil sampah TANGKASAKI' (truk angkutan sampah kita) di Kota Makassar tahun 2016 Skripsi.

4. Anton Timur Jaelani, 2011. Hubungan Pengetahuan Keselamatan Kerja Dengan Kewaspadaan Terhadap Kecelakaan Kerja Pada Karyawan Bagian Pengisian LPG PT. Pertamina Persero Fuel Retail Marketing Region VII Sulawesi

5. Dwi Yulita Sari, Sri Saptuti Wahyuningsih, 2014. Hubungan Pengetahuan Dengan Perilaku Pencegahan Kecelakaan Kerja Di Laboratorium Farmasi Poltekes Bhakti Mulia. UMS. International Journal On Medical Science. Vol 1 (2).

6. Laifatul Mufarokhah, 2016. Hubungan Pengetahuan Keselamatan Kerja Dengan Pelaksanaan Pencegahan Kecelakaan Kerja Pada Karyawan Bagian Spining Di PT. Primatexco Indonesia Batang. Universitas Negeri Semarang. Skripsi.

7. Retnoningsih, A. (2017). Analisi Faktor-faktor Kejadian Dermatitis. Diperoleh tanggal Juli 2018

dari http://repository.unimus.ac.id/226/1/FU L L_WORD1.pdf

8. Lensoni, Hartati Nety, Jumiati, Sri. 2018. Hubungan Perilaku dan Sikap Pekerja Pengangkut Sampah Dengan Penggunaan Alat Pelindung Diri Di Kampung Jawa Banda Aceh. Jurnal Aceh Medika. Vol. 2(1) 2018.

9. Diana Fitri Wijayanti. 2016. Hubungan Pengetahuan dan Tindakan Penggunaan Alat Pelindung Diri Terhadap Keluhan Gangguan Kulit Pada Petugas Sampah TPA Batu Layang Pontianak.

10. Edwina Rudyarti, 2017. Hubungan Pengetahuan Keselamatan Kerja Dan Kesehatan
Kerja Dan Sikap Penggunaan APD Dengan Kejadian Kecelakaan Kerja Pada Pengrajin Pisau Batik Di PT. X. Jurnal of Industrial Hygiene and cupational Health. Vol 2 (1) 